\title{
マルチフェーズフィールド (MPF) 法による ミクロ凝固組織と残留液相形態の解析*
}

一凝固割れ発生要因に関する検討一

福元 成雄 ${ }^{* *}$, 吉岡 優馬 ${ }^{* *}$

\begin{abstract}
Simulation of Morphologies in Solidification Microstructure and Residual Liquid by Multi-Phase Field Method*
\end{abstract} - Investigation of Factors for Solidification Cracking -

$$
\text { by FUKUMOTO Shigeo }{ }^{* *} \text { and YOSHIOKA Yuma* }
$$

\begin{abstract}
The effect of microstructural morphologies on solidification microsegregation and residual liquid distribution was investigated in Fe-Cr$\mathrm{Ni}-\mathrm{C}$ alloy, which forms the basis for austenitic stainless steel with fully $\gamma$ solidification mode by using the multi-phase field (MPF) method. When the cellular dendrite growth direction became inclined, the growth of the secondary arm became remarkable in the branching part and liquid droplets were formed irregularly around the grain boundary region. A liquid film was formed in the blocking part of inclined cellular growth, where stress concentration occurred continuously. This liquid film can influence solidification cracking susceptibility. Stress concentration occurred discontinuously in the branching part. The effect of varying the interface energy during solidification on the residual liquid morphology was not large, even when $2 \sigma_{\mathrm{L}-\gamma} \ll \sigma_{\gamma^{-}-\gamma}$, where $\sigma_{\mathrm{L}-\gamma}$ is the interface energy of liquid $/ \gamma$ and $\sigma_{\gamma^{-}-}$is the interface energy of $\gamma / \gamma$.
\end{abstract}

Key Words: austenitic stainless steel, solidification, $\gamma$ phase, microstructure, microsegregation, liquid film

\section{1. 緒言}

オーステナイト系ステンレス鋼の凝固割れは, 初晶 $\gamma$ 凝固 の場合に問題になる. $\gamma$ 相は $\delta$ 相に比べて $\mathrm{S}$ おび $\mathrm{P}$ の固溶 度が小さいため, 凝固時のミクロ偏析が増大する. 従って, 不純物元素を低減する, 適量の $\delta$ 相を含有する成分にする ${ }^{1,2)}$ などの対策が取られている.

凝固過程の固液共存域では延性が極めて低いことが知ら れており ${ }^{3,4)}$, 溶接分野ではこの温度領域を凝固脆性温度領 域（Brittleness Temperature Range: BTR）と呼び. 凝固後期 で液相が残存した部分に凝固収縮や拘束に伴う引張ひずみ が作用すると，凝固割れが発生すると推定される，BTRが 大きいほど凝固割れ感受性が高くなり, 特に S P P のよう に溶質濃化が著しい元素はBTRへの影響が大きい. BTRは, 固相内拡散を考慮した凝固ミクロ偏析の解析により求めら れる. 一般に, デンドライトの断面形状を六角形セルで近 似される ${ }^{5-7)}$. Fig. 1 にいくつかの凝固プロセスにおける凝固 速度と温度勾配の関係を示す ${ }^{8)}$. 溶接プロセスは連続鋳造に 比べて温度勾配が大きいことが特徴である. 1 次デンドライ トアーム間隔 $\lambda_{1}$ は Kurz-Fisherにより，(1)式で表わされる9).

$$
\lambda_{1}=4.3\left(\Delta \mathrm{T}_{0} \mathrm{D} \Gamma / \mathrm{k}\right)^{1 / 4} \mathrm{~V}^{-1 / 4} \mathrm{G}^{-1 / 2}
$$

\footnotetext{
*受付日 平成30年7月10日 受理日 平成30年12月3日

**正＼cjkstart員＼cjkstart新日鐵住金ステンレス株式会社Ｍember, Nippon Steel \& Sumikin Stainless Steel Corporation
}

ここで, $\Delta \mathrm{T}_{0}$ は凝固温度区間, $\mathrm{D}$ は拡散係数, $\Gamma$ は GibbsThomson 係数, $\mathrm{k}$ は分配係数, $\mathrm{V}$ は凝固速度, $\mathrm{G}$ は温度勾配 である. 溶接凝固では, 温度勾配 G が大きいために $\lambda_{1}$ が小 さい傾向にあり, また比較的凝固速度が大きいこともあり, セル凝固が生成しやすい(10) と考えられる.

溶接時の凝固割れは柱状晶の結晶粒界で観察されてお $り^{6,11-13)}$, 粒界でのミクロ偏析や残留液相の形態を明確にす ることは重要である。また, 溶接凝固割れの防止に関しては, 組織の微細化や等軸晶化が有効なこと ${ }^{14,15}, 2$ 次デンドライト アームの発達により割れにくくなることが知られており ${ }^{3,4)}$, 結晶粒界が凹凸化することによって割れ感受性の低減が予

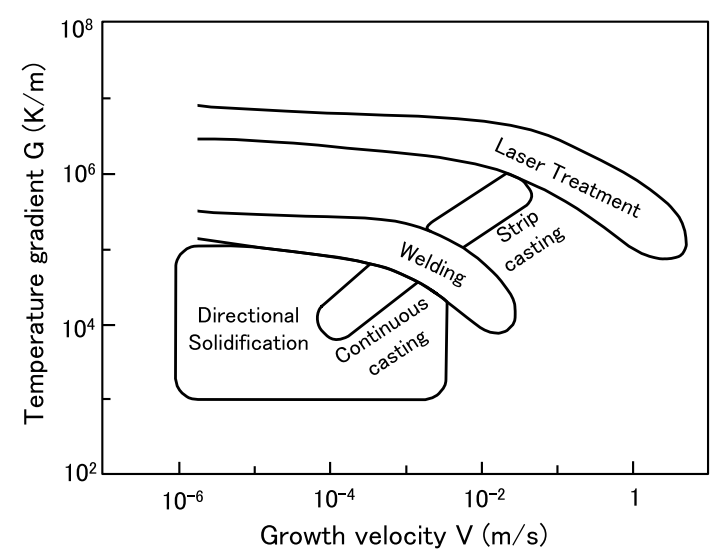

Fig. 1 G-V diagram for different solidification process (Redrawn from ref. 8). 
想される。したがって，ミクロ偏析や残留液相形態に及ほ すミクロ組織形態の影響は明確にすることは重要である. さらに, $\mathrm{Ni}$ 基合金では, バイクリスタルのレーザー溶接に おける凝固割れが調査されている ${ }^{16)}$. 結晶方位の差が大きく なると凝固割れが発生することが示されており，結晶方位 の差によって粒界エネルギーが大きくなり，低温側まで粒 界に液相が残留しやすくなるために割れが発生すると考え ている. 界面エネルギーや残留液相の分布も凝固割れ発生 要因として評価すべきものといえる.

マルチフェーズフィールド (Multi-phase field: MPF) 法 ${ }^{17-19)}$ は多相系および多結晶系の組織形成を解析でき，凝固時の 複雑なセル・デンドライト形状が再現できる，MPF 法は不 均一な凝固における組織形態とミク口偏析を推定する手法 としても有効と考えられる ${ }^{20,21)}$. 本報告ではMPF 法を用い て, 凝固後半の組織形態について, 特にセル・デンドライ 卜成長方向や界面エネルギーの影響に注目しながら解析し た結果について述べる．本論文は，ミクロ凝固組織と残留 液相の形態の関係を推定し, 残留液相形態の凝固割れ感受 性への寄与を推定することを目的としている.

\section{2. 解 析 方 法}

\section{1 計算条件}

本研究では, $\mathrm{Fe}-\mathrm{Cr}-\mathrm{Ni}-\mathrm{C}$ 系において, MICRESS (ver. 6.4) ソフトウェア ${ }^{17)}$ を用いた組織形成に関する計算を実施した。 今回は熱力学データベースの信頼性も高く, 分配係数が比 較的小さいためにミクロ偏析も顕著な $\mathrm{C}$ を含有した 4 元系 で解析を行った，MPF法による解析の詳細は文献 18) など に記載されている。，一定格子幅の空間直交格子の差分法に より二次元における解析を行っており, CALPHADソフト ウェアの Thermo-Calc ${ }^{22)}$ と連携して, 自由エネルギーと移動 度の計算に熱力学データベースと拡散データベースを提供 している. 熱力学データベースは TCFE ver.7を, 拡散デー タベースはMOB2を用いた。

計算における温度条件は文献 23) を参考にし，TIG 溶接を 想定して冷却速度 $83 \mathrm{~K} / \mathrm{s}$ ，温度勾配 $492 \mathrm{~K} / \mathrm{cm}$ とした。定常
時の凝固速度は冷却速度／温度勾配になる。また， 1 次デン ドライトアーム間隔も従来知見 ${ }^{23,24)}$ を参考に設定したが，(1) 式を考慮して成分 $\left(\Delta \mathrm{T}_{0}\right)$ に応じて変化させた. Fig. 2 に計 算領域サイズの例を示す. 初晶 $\gamma$ 相のデンドライト $\left(\gamma_{1} \sim \gamma_{4}\right)$ 位置として 4 箇所に設定している．計算の格子幅は $0.10 \mu \mathrm{m}$ とし，界面領域幅は 4 格子とした。 また，計算成分および 初期条件を Table 1 に示す。成分は Fe-25\% Cr-22\% Ni$0.02 \% \mathrm{C}$ 系で, $\gamma$ 単相で凝固する $\mathrm{A}$ 凝固モードで, 系内の成 分保存則を適用した。 case 2,3,5 は一部のデンドライト成長 方向を $\mathrm{Y}$ 方向から $5^{\circ} \sim 10^{\circ}$ 傾けて, 成長方向と溶質濃化お よび組織形態の関係を評価している。初晶 $\gamma$ 相生成の初期温 度としては, KGT (Kurz-Giovanola-Trivedi） モデル25,26)によ り計算されたデンドライト先端温度（凝固速度 $1.67 \mathrm{~mm} / \mathrm{s}$ に おける）を採用し，定常状態に短時間で達するようにした ${ }^{19)}$. Table 1 には計算に用いた界面エネルギー, 界面モビリティ などの解析条件も示している。なお，今回の解析では界面 モビリティは自動設定として計算の収束性を上げるように した．詳細は文献 27) に解説されているが，今回の計算では $0.07 \mathrm{~cm}^{4} / \mathrm{J} / \mathrm{s}$ 程度の值となった。従来の解析結果 ${ }^{18,19)}$ と比較し て大きい值を用いているが，界面幅を小さくした影響と考え られ, 従来と同様の計算結果が得られることは確認している. その他の值は文献 19) および 28) を参考にして設定した。 $\varepsilon_{4}$

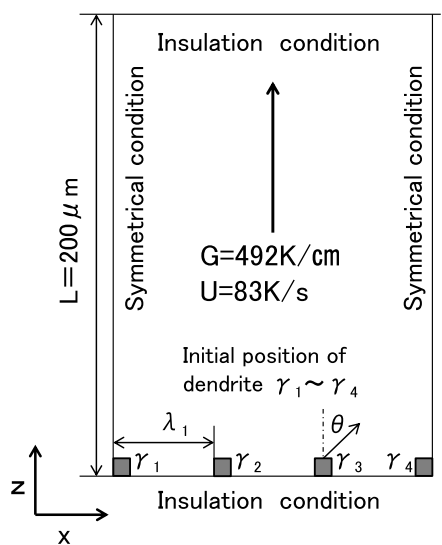

Fig. 2 Schematic illustration of calculation region and boundary conditions.

Table 1 Parameter values in the MPF simulation.

\begin{tabular}{|c|c|c|c|c|c|c|c|c|c|c|c|}
\hline \multirow{2}{*}{ case } & \multirow{2}{*}{ steel $*$} & \multirow{2}{*}{$\begin{array}{c}\text { arm spacing, } \\
\lambda_{1}(\mu \mathrm{m})\end{array}$} & \multicolumn{4}{|c|}{ angle of growth direction, $\theta$} & \multirow{2}{*}{$\begin{array}{c}\text { initial } \\
\text { temperature } \\
\text { (K) }\end{array}$} & \multirow{2}{*}{$\begin{array}{c}\text { interface } \\
\text { mobility, M } \\
\left(\mathrm{cm}^{4} / \mathrm{J} / \mathrm{s}\right)\end{array}$} & \multirow{2}{*}{$\begin{array}{l}\text { anisotropy } \\
\text { of } \mathrm{M}, \varepsilon_{4}\end{array}$} & \multirow{2}{*}{$\begin{array}{l}\text { interface energy } \\
\text { of } \mathrm{L} / \gamma, \sigma\left(\mathrm{J} / \mathrm{m}^{2}\right)\end{array}$} & \multirow{2}{*}{$\begin{array}{c}\text { anisotropy } \\
\text { of } \sigma, \varepsilon_{4}\end{array}$} \\
\hline & & & $\gamma 1$ & $\gamma 2$ & $\gamma 3$ & $\gamma 4$ & & & & & \\
\hline 1 & A & 22 & $0^{\circ}$ & $0^{\circ}$ & $0^{\circ}$ & $0^{\circ}$ & 1686.0 & \multirow{5}{*}{$* *$} & \multirow{5}{*}{0.0067} & & \multirow{5}{*}{0.013} \\
\hline 2 & A & 22 & $0^{\circ}$ & $5^{\circ}$ & $5^{\circ}$ & $0^{\circ}$ & 1686.0 & & & $3 \times 10^{-5}$ & \\
\hline 3 & A & 22 & $0^{\circ}$ & $10^{\circ}$ & $10^{\circ}$ & $0^{\circ}$ & 1686.0 & & & & \\
\hline 4 & A & 22 & $0^{\circ}$ & $0^{\circ}$ & $0^{\circ}$ & $0^{\circ}$ & 1686.0 & & & $* * *$ & \\
\hline 5 & A & 22 & $0^{\circ}$ & $10^{\circ}$ & $10^{\circ}$ & $0^{\circ}$ & 1686.0 & & & $* * *$ & \\
\hline
\end{tabular}

* steel $\mathrm{A}: \mathrm{Fe}-25 \% \mathrm{Cr}-22 \% \mathrm{Ni}-0.02 \% \mathrm{C}$

** automatic interface mobility mode

$* * * \geqq 1672 \mathrm{~K}: \sigma=3 \times 10^{-5}, 1655 \leqq \mathrm{~T} \leqq 1672 \mathrm{~K}$ : linear approximation, $\leqq 1655 \mathrm{~K}: \sigma=1 \times 10^{-5}$ 
は異方性の強度を表わす係数である。これは 4 回対称の界 面エネルギー異方性における結晶界面形状の平衡解で, 比 較的異方性が弱い金属の凝固などで用いられる．同様の取扱 いは界面モビリティに関しても適用している. $\sigma_{\gamma^{-\gamma}}=0.5 \mathrm{~J} / \mathrm{m}^{2}$ とした。なお, 今回の計算では, 固相率 (fs) が 0.95 程度ま たは 0.98 程度における偏析と残留液相形態, 凝固温度 ( Tf ) を評価した. Tfは凝固初期の底部と上部の非定常部位を含 んだ系全体で凝固が完了する際の底部の温度である。凝固 初期の底部には核生成・成長の影響でデンドライト樹間に 液滴が残存する部分が存在する。上部には系内の成分保存 則を適用している関係で不均一に凝固する部分が発生する. BTRを決定するために, Tfを用いることは適当でないが, ここでは条件間の比較を行う意味で，Tfを用いた。また， 計算により得られた組織の評価は, 底部および上部 $20 \mu \mathrm{m}$ 長 さを非定常部と考えて除外し, 定常的な一方向凝固の状態 が得られる部分の観察で行った。

\section{2 界面エネルギーの影響}

Table 1 の case 6,7 では底部の温度 1672〜 1645Kの間でミ クロ偏析に伴って界面エネルギーが直線的に低下すると仮 定している。凝固末期の組織形成における界面エネルギー の影響について検討する. Al 合金において，凝固末期の液 膜形状は鋳造や溶接時の凝固割れに影響を及ぼすことが示 されている ${ }^{29)}$. 固液間の濡れ性がよく, 接触角 $\theta$ が小さい場 合には割れが発生しやすい. 鉄鋼材料では $\sigma_{\mathrm{L}-\gamma}=0.3 \mathrm{~J} / \mathrm{m}^{2}$, $\sigma_{\gamma^{-} \gamma}=0.5 \sim 0.9 \mathrm{~J} / \mathrm{m}^{2}$ と推定される ${ }^{30-33)}$. 一般に界面の力学的関 係は次式で表わされる.

$$
\sigma_{\mathrm{L}-\gamma}=\sigma_{\gamma}+\sigma_{\mathrm{L}} \cos \theta
$$

ここで， $\sigma_{\gamma}$ および $\sigma_{\mathrm{L}}$ は $\gamma$ 相および液相の表面エネルギーであ る. 粒界における液相の残存に関しては, $2 \sigma_{\mathrm{L}-\gamma}<\sigma_{\gamma^{-} \gamma}$ で液 膜状に残存し，鉄鋼材料の割れ感受性を高める可能性がある.

また，Girifalco-Good ${ }^{34)}$ は，異相間の界面エネルギーの関 係式を提案し, 溶鉄系の界面エネルギーの推定にも活用さ れている ${ }^{35)}$.この考え方によると, 界面エネルギーは次式で 表わされる.

$$
\sigma_{\mathrm{L}-\gamma}=\sigma_{\mathrm{L}}+\sigma_{\gamma}-2 \phi_{\mathrm{L}-\gamma}\left(\sigma_{\mathrm{L}} \cdot \sigma_{\gamma}\right)^{1 / 2}
$$

ここで， $\phi_{\mathrm{L}^{-} \gamma}$ は界面の結合様式に係わる定数で, 結合様式 が類似するほど 1 に近く，異なるほど小さくなる．溶鉄系 では微量元素（例えば，C）の増大により液相の表面エネル ギーが低下し ${ }^{36,37)}$, 界面エネルギーも増大することが知られ ている38,39).（3)式において， $\phi_{\mathrm{L}-\gamma}$ は小さい值であり，液相 の表面エネルギーの低下に伴って固液の界面エネルギーも 低下すると予想される，従って，ミクロ偏析による溶質濃 化で界面エネルギーが変化するため, 最終凝固の液相形態 に及ぼす界面エネルギー（ミクロ偏析による界面エネルギー の減少）の影響を評価すべきと考えられる，なお，従来の 解析によると ${ }^{38)}$, 界面エネルギーに及ぼす炭素濃度の影響は
高濃度では飽和する傾向にあり, そのことは(3)式からも予 想される. 以上の検討結果にもとに, ミクロ偏析に伴って 界面エネルギーが低下すると仮定した解析を行った。

\section{3 応力解析}

Uehara はPF 法によりミクロ組織形成と応力解析を行って いる ${ }^{40)}$. Ni-Cu 合金の一方向凝固において, 隣接するセルの 競合が起こると液相の溝部や固相中に液滴が形成され，そ の周囲に大きな応力集中が生じることを示している.今回 の解析に対応させて考えると, blocking 部では液膜と液滴が 連続して形成されるので, 応力集中する可能性が高いとい える．不均一凝固による局部的な応力集中が割れの原因に なることも考えられる.

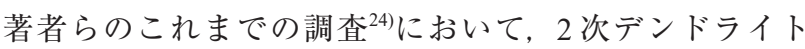
アームの発達により凝固割れが発生しにくくなる傾向が得 られ，従来から界面形状の凹凸化することによって割れ感 受性が低減することが知られている，凝固割れの感受性は BTR, 割れ限界ひずみとひずみ曲線の関係で評価する方法 が確立されているが ${ }^{3,4)}$, 本研究ではセル /デンドライトお よび残留液相の形態に着目し, 固相が接触する際に発生す ると予想される応力集中に関して解析を行った.

MICRESS には応力ーひずみモジュールがあり，ミクロ組 織内部の応力分布を解析できる. 系の自由エネルギーとし て，通常のバルクの自由エネルギーと勾配エネルギー項に 弾性ひずみエネルギー項を加えている．モデルの詳細につ いては, 文献 41)に解説されている. 今回の解析では, Fig. 2 および Table 1 の case 3 の条件を元に計算を行った. ま た，Fig. 2 の 方向に $10 \mathrm{MPa}$ の引張を付与した。境界条件は 原点固定で, 底部の Z 方向拘束およびX方向自由, 左面の $\mathrm{Z}$ 方向自由および $\mathrm{X}$ 方向拘束, 右面の $\mathrm{X}$ 方向に一様引張応 力を付与している. 解析には Table 2 の物性值を用いた。 液 相の挙動を定量的に取り扱うことは難しいが, 仮想的に小 さな弾性係数の 2 水準を液相に与えることにした．また， $\gamma$ 相の弾性係数は文献 42)における計算值から推定した. なお, 弾性係数の温度依存性は無視したが, 液相の取り扱いの適 正化や物性值の最適化は今後の課題である.

\section{3. 解析結果および検討}

\section{1 デンドライト成長方向の影響}

Fig. 3 に 0.15 秒における相分布と組織形態を case 1 〜 3 で 比較して示す. case 1 では初期から均一なセル凝固が進行し ているのに対して, case 2 と case 3 では $\gamma_{1}$ と $\gamma_{2}$ の間が広がる ために 2 次デンドライトアームの成長が認められ, 特に $10^{\circ}$ 傾

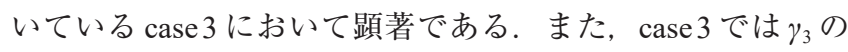
成長が両側のセル／デンドライト成長による溶質濃化の影響 を受けて抑制・淘汰されている。 なお， case 3 において， $\gamma_{1}$ と $\gamma_{2}$ の 2 次デンドライトアームの接触は約 $100 \mu \mathrm{m}$, 約 $160 \mu \mathrm{m}$ 位置で各々 $0.17 \mathrm{~s}, 0.20 \mathrm{~s}$ であったのに対して, $\gamma_{3}$ と $\gamma_{4}$ のセ 
Table 2 Materials properties in the MPF simulation.

\begin{tabular}{|c|c|c|c|c|c|c|c|}
\hline \multirow[b]{2}{*}{ case } & \multirow{2}{*}{ steel $*$} & \multirow{2}{*}{ phase } & \multirow{2}{*}{$\begin{array}{c}\text { molar volume } \\
\left(\mathrm{m}^{3} / \mathrm{mol}\right)\end{array}$} & \multicolumn{3}{|c|}{ elastic coefficient (GPa) } & \multirow{2}{*}{$\begin{array}{c}\text { thermal } \\
\text { expansion } \\
\left(10^{-5}, \mathrm{~K}^{-1}\right)\end{array}$} \\
\hline & & & & C11 & C12 & C44 & \\
\hline \multirow{2}{*}{$3-2$} & \multirow{4}{*}{ A } & liquid & 7.915 & 36 & 14 & 11 & - \\
\hline & & $Y$ & 7.468 & 139 & 86 & 81 & 2 \\
\hline \multirow{2}{*}{$3-3$} & & liquid & 7.915 & 2 & 2 & 1 & - \\
\hline & & Y & 7.468 & 139 & 86 & 81 & 2 \\
\hline
\end{tabular}

* steel $\mathrm{A}: \mathrm{Fe}-25 \% \mathrm{Cr}-22 \% \mathrm{Ni}-0.02 \% \mathrm{C}$

case 1
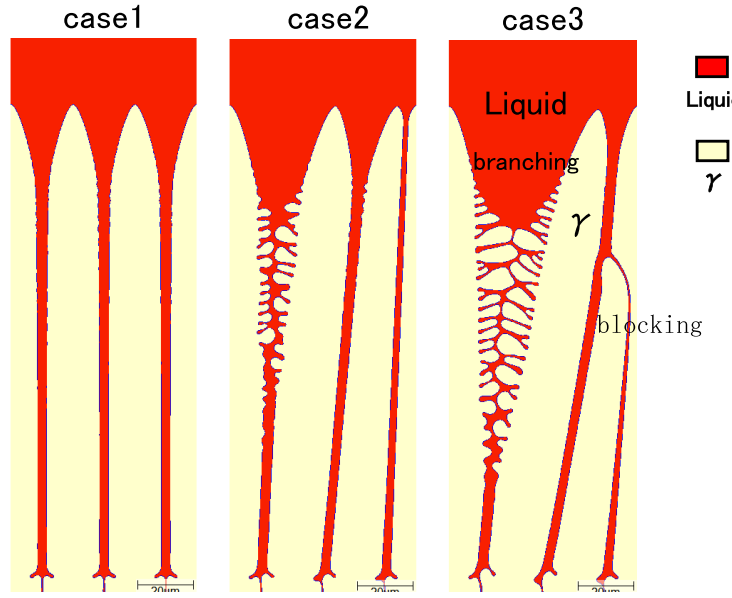

Fig.3 Distribution of phase calculated by MPF method $(0.15 \mathrm{sec})$.

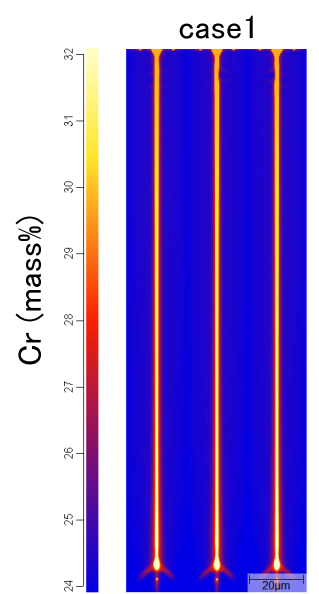

$\mathrm{fs}=0.939$ case2

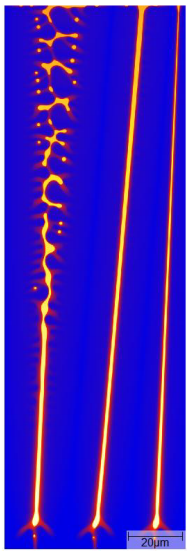

$\mathrm{fs}=0.944$ case 3

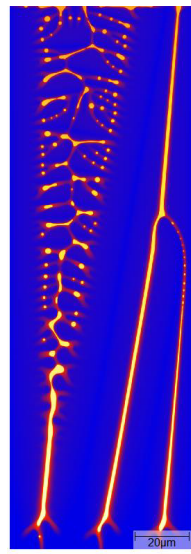

fs $=0.951$
Fig. 4 Distribution of Cr content calculated by MPF method $(0.30 \mathrm{sec})$.

ルの接触は約 $110 \mu \mathrm{m}$ 位置で $0.23 \mathrm{~s}$ であり，デンドライトに 比べて遅れていた

Fig. 4 に 0.30 秒における $\mathrm{Cr}$ 濃度の分布を比較して示す．凝 固偏析により溶質元素の濃化した液相部に着目すると, case 1 はセル凝固で, 直線的なミクロ偏析であるのに対して, case 2,3では 2 次デンドライトアームの成長した領域 （branching 部）で偏析が点状に分散した部分があることが特 徵である.また，成長をブロックされた case 3 における $\gamma_{3}$ (blocking 部) では, case 1 と同様に液膜状の偏析が残る側と

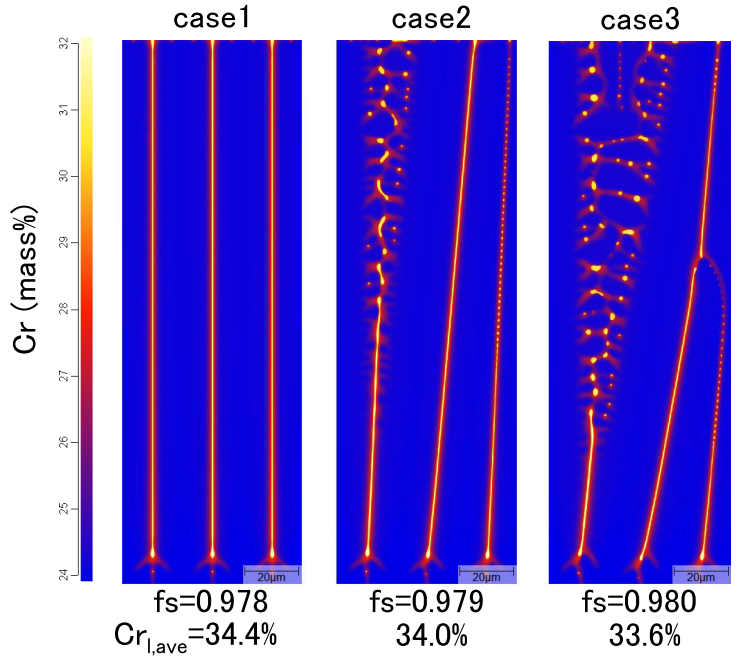

Fig.5 Distribution of $\mathrm{Cr}$ content calculated by MPF method $(1.0 \mathrm{sec})$.

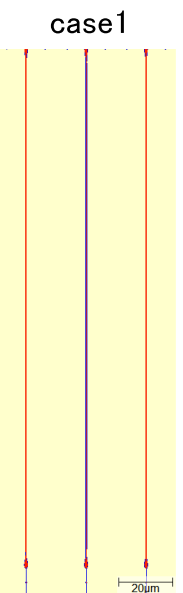

$\mathrm{Tf}=1605 \mathrm{~K}$

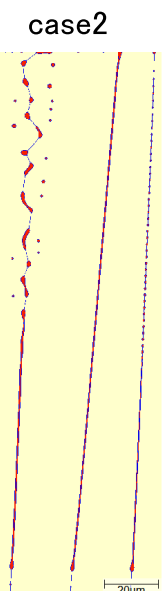

$1607 \mathrm{~K}$

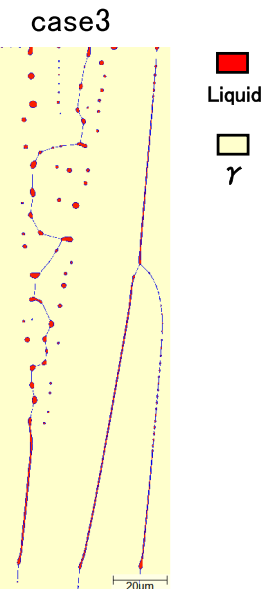

$1613 \mathrm{~K}$
Fig. 6 Distribution of phase calculated by MPF method (1.0sec)

曲率を有して偏析が早めに液滴化する側が存在する．3つの 計算における固相率を比べると，固相率は $0.94 \sim 0.95$ 程度 で大きな差はないが, case 1 や case 2 がわずかに case 3 より 小さい結果になった.

Fig. 5 に 1.0 秒における Cr 濃度の分布，Fig. 6 に相分布を示 す.いずれの場合も固相率は 0.98 程度であったが, 2 次デン ドライトアームが成長した case 3 で若干高くなった。また, 
図中に示した $\mathrm{Cr}_{1, \mathrm{ave}}$ は系全体における液相中の平均 $\mathrm{Cr}$ 濃度 を示している. case 3 の $\mathrm{Cr}_{1, \text { ave }}$ は case 1 に比べて $1 \%$ 弱少ない. 液相中の $\mathrm{Cr}$ 濃度に大きな差はないが, case 3 の branching 部 では Cr 濃度 $\geqq 32 \%$ の偏析部が粒状に分散する傾向にあり, blocking 部も含めて粒界に相当する部分における偏析の増大 は認められなかった。 また, 凝固温度 Tf は成長方向の傾き が大きい case 3 で高い結果が得られた。相および Cr 濃度の 分布から残留液相の形態を推定すると, case 1 のセル凝固で

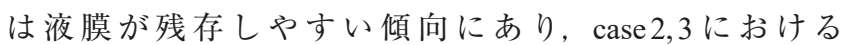
blocking 部でも液膜状の部分が見られる。一方，2次デンド ライトアームが成長した branching 部は液滴状であり，例え ば case 2 および case 3 の $\gamma_{1}$ と $\gamma_{2}$ 間で観察される．特に成長方 向差の大きい case 3 では結晶粒界も凹凸で，直線的ではなく なり, 凝固割れの進展を抑制できる可能性があるといえる ${ }^{29}$.

デンドライト成長の branching 部は液滴が生成しやすく, セル凝固の blocking 部は液膜が生成しやすいと推察される. 実際の割れ形態は 3 次元的で複雑なために明確な傾向を示 すことは難しいが，バレストレイン試験に関する従来知見 において ${ }^{6,13)}$, セル間の blocking 部で割れが発生する場合が 見られる。本計算では凝固収縮を考慮していないため，凝 固収縮に伴う液相の移動（溶質濃化）を無視しているが, 今回の結果から推察すると, 特にセルが競合成長する blocking 部では界面またはその近傍は液膜が主体で，液滴が 連続的に残存しやすく, 成長方向差によって凝固収縮に伴 う引張ひずみが大きくなるために割れが発生しやすくなる 可能性がある. なお, 結晶粒選択部における偏析の計算結 果 ${ }^{20,21)}$ や実験結果 ${ }^{43-45)}$ において, 粒界部分における顕著な偏 析傾向は本研究と同様に認められていない.

\section{2 界面エネルギー変化の影響}

Fig. 7 に case 4, 5 における計算結果として, 1.0 秒後の $\mathrm{Cr}$ 濃
度の分布を示す．図中に示した $\mathrm{Cr}_{1, \text { ave }}$ は系全体の液相中の平 均 $\mathrm{Cr}$ 濃度を示している. case 4 では2 次アームの成長はなく, セル状凝固の形態となっており, case 1 の組織形態や偏析と 同等で，デンドライト樹間における $\mathrm{Cr}$ のミクロ偏析が液膜 状に観察できる。 0.20 秒までは case 5 と case 3 で界面エネル ギーに差がなく，その後デンドライト樹間で溶質濃化が起 こり，界面エネルギーの変化が仮想的に与えられる。 case 5 と case 3 の Cr 濃度分布を比較すると, $\mathrm{Cr}$ 濃化部の形態に大 きな差は認められない. 凝固後半で $2 \sigma_{\mathrm{L}^{-} \gamma} \ll \sigma_{\gamma^{-}}$となる case 5 では，液滴が少なく，液膜が存在しやすい傾向にあるが, 液相率は case 4 と case 1 , case 5 と case 3 でほぼ同じである. また, 凝固温度 $\mathrm{Tf}$ の差も約 $2 \mathrm{~K}$ 程度であった。凝固中の溶 質濃化に伴って, 液相 $-\gamma$ 相の界面エネルギーが大きく低下 すると液膜が残存しやすく，凝固割れ感受性を高めると考 えられるが，今回の解析からは界面エネルギー変化の影響 による凝固温度 Tfへの大きな影響は見出せなかった。なお， 界面エネルギーの影響としては液相の流動性や濡れ性の向 上が挙げられるが，今回の解析はメゾスコピックなもので あり，また液相の移動は考慮しておらず，更なる検討が必 要と考えられる.

\section{3 応力分布の解析}

Fig. 8 に case 3-2 の条件で fs=0.95 における応力分布を計算 した結果を示す． $\sigma_{\mathrm{xx}}$ は付加応力に対応し， $\sigma_{\mathrm{zz}}$ は温度勾配に 対応した凝固時の体積収縮による応力分布であるが，せん 断応力 $\sigma_{\mathrm{xz}}$ は凝固組織形態に対応した分布を示していると推 察される. blockingされたセル $\gamma_{3}$ がセル $\gamma_{4}$ に接触した部分 ではセル先端部に応力が生じる。また, 液膜の形成したセ ル間にも数 $\mathrm{MPa}$ 程度の引張応力が生じる可能性が示唆され る.一方, branchingによりデンドライトが成長した部分に も応力集中が見られるが, 凹凸の大きい界面では応力が比

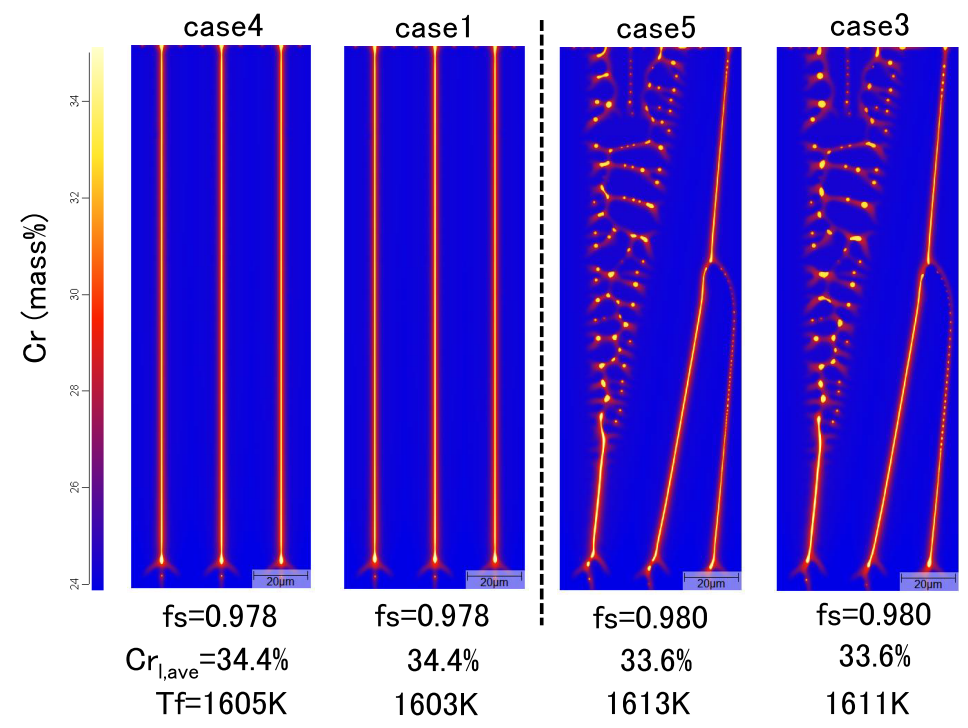

Fig. 7 Effect of interfacial energy on distribution of Cr content calculated by MPF method $(1.0 \mathrm{~s})$ 

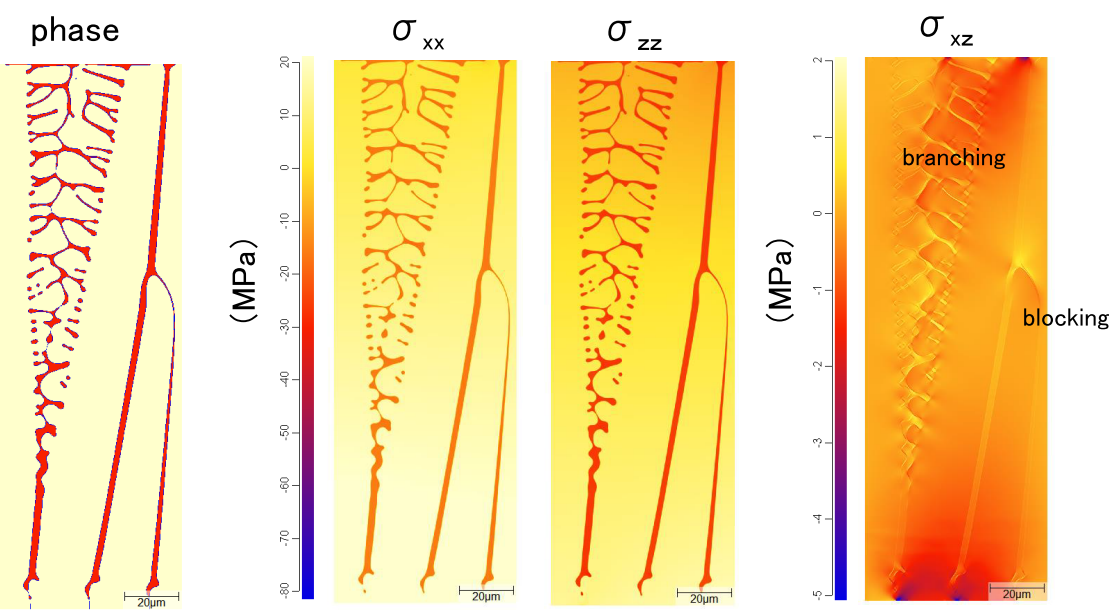

Fig. 8 Distribution of phase and stress calculated by MPF method (case 3-2, $0.21 \mathrm{~s}$, fs $=0.95)$.

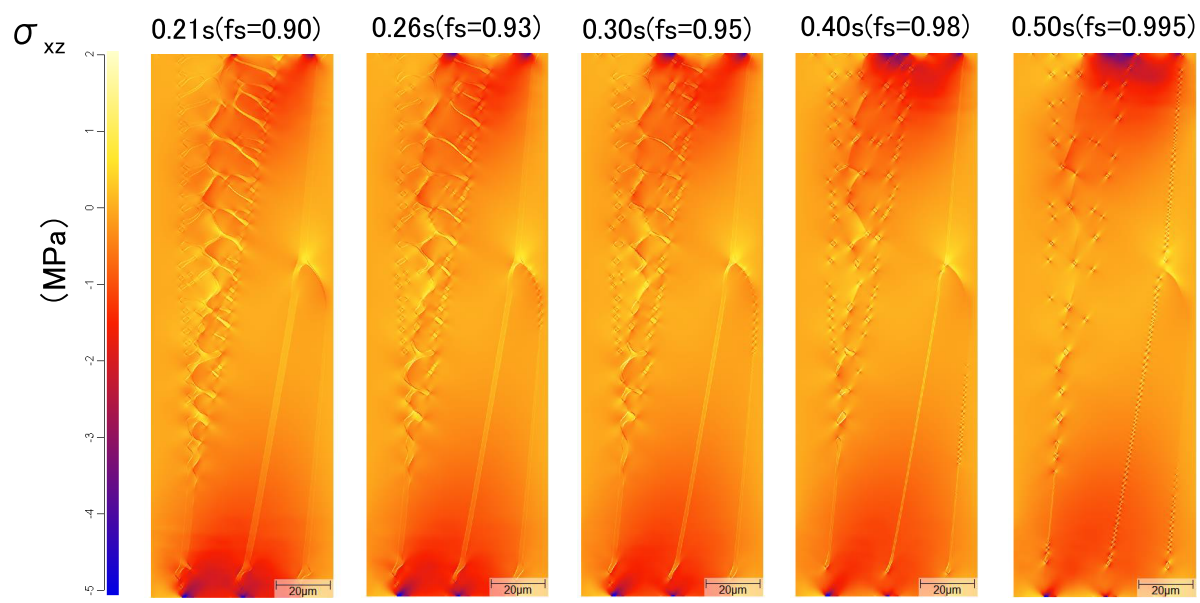

Fig.9 Stress distribution $\left(\sigma_{\mathrm{xz}}\right)$ calculated by MPF method in case 3-2.

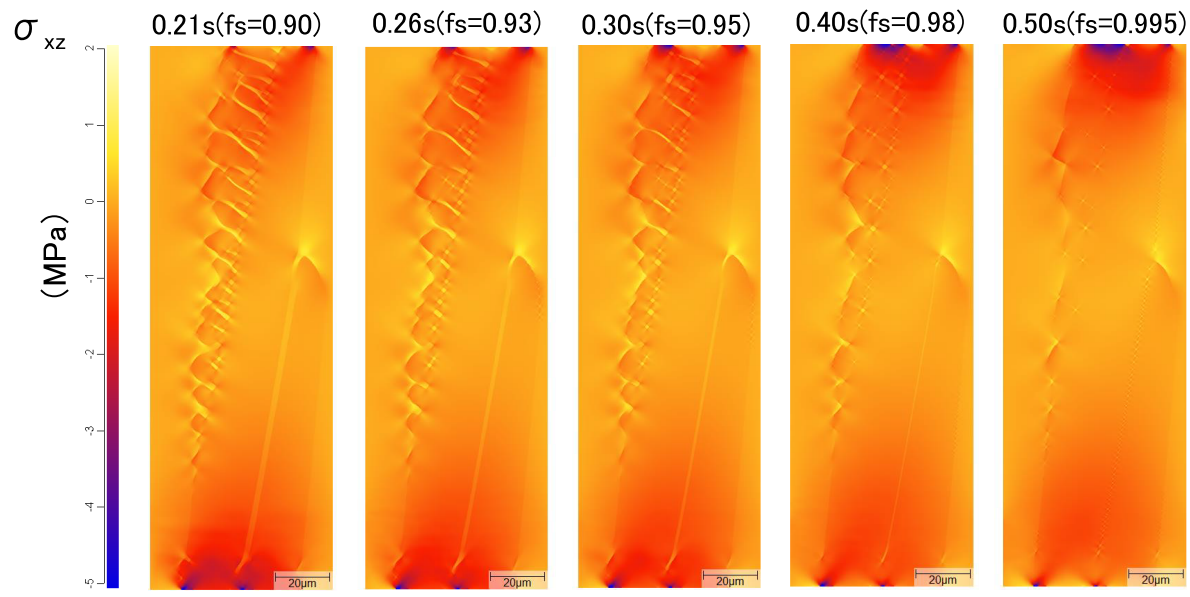

Fig.10 Stress distribution $\left(\sigma_{\mathrm{xz}}\right)$ calculated by MPF method in case 3-3.

較的小さく，分布も不連続になることが特徴といえる.

Fig.9 および Fig. 10 に case 3-2,3-3におけるせん断応力分布 を比較して示す。セル接触部抒よびセル間の応力集中は case3-2で若干大きく，デンドライト樹間では組織の微細分 散化に伴って応力集中が軽減される傾向にあると考えられ
る。なお，上部の高温側で時間経過とともに圧縮応力が発 生するが，境界条件や凝固組織形態等に起因する非定常なも のと推定され，今回の解析では blocking 部抢よび branching 部に着目した，本解析における応力分布と割れ感受性を対 応させることは困難であるが，従来知見を参考にすると， 
blocking 部のセル結合および周辺のセル間ではせん断応力が 発生し, 固相の接触もデンドライト部に比べて遅れると推 定されるため, 割れが発生しやすい領域であると推察され る. 解析における液相の取り扱いの適正化や割れ感受性と の対応を明確にすることは今後検討すべき課題である，本 項では応力集中に着目して解析を行ったが，MPF 法を活用 して温度と固相率の関係を推定し，ひずみ速度 ${ }^{46)}$ を求めるこ とで割れ感受性を予測する方法も示されており ${ }^{47)}$ ，今後も MPF 法は凝固組織予測において重要になってくると考えら れる。

\section{4. まと め}

オーステナイト系ステンレス鋼が凝固する際の残留液相 形態に着目し，組織形態の影響をMPF 法によるシミュレー ション解析により評価し, 以下の結果が得られた。

（1）セル／デンドライトの成長方向が傾くと, branching 部で は2 次デンドライトアームの成長が顕著になり, 液滴の形 成や粒界の凹凸化が観察されるが，七ル凝固の blocking 部では液膜と液滴が連続的に生成し, 凝固収縮時の引張 ひずみにより割れが発生しやすいと考えられる。

(2) 溶質濃化による界面エネルギー低下を考慮すると液膜が 残存し易い傾向にあるが，今回の計算条件では凝固温度 への影響は大きくないと推察される.

(3) blocking 部ではセル先端および液膜の形成したセル間で せん断応力が発生し, 割れが発生やすい領域であると推 定される。一方, branchingによりデンドライトが成長し た部分にも応力集中が見られるが，凹凸の大きい界面では 応力が比較的小さく, 分布も不連続になると考えられる.

\section{謝辞}

本研究の応力解析を実施するにあたり, 有益なアドバイ スを頂きました伊藤忠テクノソリューションズ株)の野本祐 春博士と瀬川正仁氏に心から感謝いたします.

\section{参 考 文 献}

1) V. Kujanpaa, N. Suutala, T. Takalo and T. Moisio: Correlation Between Solidification Cracking and Microstructure in Austenitic and Austenitic-Ferritic Stainless Steel Welds, Weld. Res. Int., 9(1979), 55-76.

2) T. Takalo, N. Suutala and T. Moisio: Austenitic Solidification Mode in Austenitic Stainless Steel Welds, Metall. Trans. A, 10(1979), 11731181.

3) T. Senda, F. Matsuda, G. Takano, K. Watanabe, T. Kobayashi and T. Matsuzaka: Studies on Solidification Crack Susceptibility for Weld Metals with Trans-Varestraint Test (1), J. Jpn. Weld. Soc., 41(1972), 709-723. (in Japanese)

4) K. Shinozaki, M. Yamamoto, P. Wen and T. Tamura: Prediction of Occurrence of Solidification Cracking in Weld Metal, J. Jpn. Weld. Soc., 74(2008), 284-289. (in Japanese)

5) Y. Ueshima, N. Komatsu, S. Mizoguchi and H. Kajioka: Effects of
Alloying Elements on Interdendritic Microsegregation of Carbon Steel, Tetsu-to-Hagané, 73(1987), 1551-1558. (in Japanese)

6) K. Saida, Y. Okabe, K. Hata, K. Nishimoto, K. Kiuchi and J. Nakayama: Hot Cracking Behaviour and Susceptibility of Extra High Purity Type 310 Stainless Steels, Sci. Technol. of Welding and Joining, 15-1(2010), 87-96.

7) T. Ogura, T. Masaki, K. Saida, K. Nishimoto, K. Kiuchi and J. Nakayama: Hot Cracking Susceptibility of Extra High-Purity Type 304 and 316 Stainless Steels, Q. J. Jpn. Weld. Soc., 33(2015), 295308. (in Japanese)

8) W. Kurz and R. Trivedi: Modern Solidification Theory Applied to Welding, Proc. 4th Int. Conf.: Trends in Welding Research, ed. by H. B. Smartt, J. A. Johnson and S. A. David, ASM International Materials Park, (1995), 115-120.

9) W. Kurz and D.J. Fisher: Dendrite Growth at the Limit of Stability: Tip Radius and Spacing, Acta Metall., 29(1981), 11-20.

10) W. Kurz and D.J. Fisher: Fundamentals of Solidification, Trans. Tech. Publications, Aedermannsdorf, Switzerland, (1989), 84.

11) Y. Nakao, K. Shinozaki, T. Ogawa and H. Sakurai: Fractography on Microcracks in Ni-Base Multi-Pass Weld Metals -Study on Microcracks in Multi-Pass Weld Metals of Ni-Base Alloys (Part 1)Q. J. Jpn. Weld. Soc., 11(1993), 102-107. (in Japanese)

12) T. Nishibata, H. Hirata, K. Ogawa and Y. Komizo: Effect of N Content on Weld Hot Cracking Susceptibility of Fully Austenitic FeCr-Ni Alloy - Investigation on Weld Hot Cracking Susceptibility of Fully Austenitic Fe-Cr-Ni Alloy (Report 1)-, Q. J. Jpn. Weld. Soc., 19(2001), 77-84. (in Japanese)

13) K. Saida, K. Hata, Y. Nishijima, H. Ogiwara, K. Nishimoto, K. Kiuchi and J. Nakayama: Hot Cracking Susceptibility in AntiIntergranular Corrosion 25Cr-35Ni Extra High-Purity Stainless Steels, Q. J. Jpn. Weld. Soc., 29(2011), 187-196. (in Japanese)

14) F. Matsuda, K. Nakata, Y. Nishio, K. Tsukamoto and S. Johgan: Effect of Zirconium Addition on Improvement of Solidification Crack Susceptibility of Al-Zn-Mg Alloy Weld, Q. J. Jpn. Weld. Soc., 4(1986), 115-120. (in Japanese)

15) Y. Murata: Welding Consumables of Stainless Steels for Automotive Exhaust System Components, J. Jpn. Weld. Soc., 72(2003), 561-565. (in Japanese)

16) N. Wang. S. Mokadem, M. Rappaz and W. Kurz: Solidification Cracking of Superalloy Single- and Bi-Crystals, Acta Mater. 52(2004), 3173-3182.

17) I. Steinbach, F. Pezzolla, B. Nestler, M. Seeßelberg, R. Prieler, G. J. Schmitz and J. L. L. Rezende: A Phase Field Concept for Multiphase Systems, Physica D, 94(1996), 135-147.

18) S. Fukumoto and S. Nomoto: Microstructure Simulation for Solidification of Stainless Steel by Multi-Phase Field Model, J. Jpn. Inst. Met., 73(2009), 502-508. (in Japanese)

19) S. Fukumoto and H. Inoue: Evaluation of Microstructure formation in SUS304 by Multi-Phase-Field Method, Q. J. Jpn. Weld. Soc., 29(2011), 197-203. (in Japanese)

20) J. Li, Z. Wang, Y. Wang and J. Wang: Phase-Field Study of Competitive Dendritic Growth of Converging Grains during Directional Solidification, Acta Mater., 60(2012), 1478-1493.

21) T. Takaki, M. Ohno, T. Shimokawabe and T. Aoki: Two-Dimensional Phase-Field Simulations of Dendrite Competitive Growth during the Directional Solidification of a Binary Alloy Bicrystal, Acta Mater. 81(2014), 272-283.

22) B. Sundman, B. Jansson and J. O. Andersson: The Thermo-Calc Databank System, CALPHAD, 9(1985), 153-190.

23) Y. Yoshioka and S. Fukumoto: Effect of Phosphorus on Solidification Characteristics in Austenitic Stainless Steels - Investigation of Factors of Solidification Cracking-, Q. J. Jpn. Weld. Soc, 35(2017), 135-140. (in Japanese) 
24) Y. Yoshioka and S. Fukumoto: Effects of Phosphorus and Nitrogen on Solidification Cracking Susceptibility in Fully Austenitic Stainless Steel, Preprints of the National Meeting of JWS, 2017s, 303. (in Japanese)

25) W. Kurz, B. Giovanola and R. Trivedi: Theory of Microstructural Development during Rapid Solidification, Acta Metall., 34(1986), 823-830.

26) S. Fukumoto and W. Kurz: Prediction of the $\delta$ to $\gamma$ Transition in Austenitic Stainless Steels during Laser Treatment, ISIJ Int., 38(1998), 71-77.

27) A. Carré, B. Böttger and M. Apel: Implementation of an Antitrapping Current for a Multicomponent Multiphase-Field Ansatz, J. Cryst. Growth, 380(2013), 5-13.

28) D. Wang, K. Kadoi and K. Shinozaki: Prediction of Residual Liquid Distribution of Austenitic Stainless Steel during Laser Beam Welding Using Multi-Phase Field Modeling, ISIJ Int., 57(2017), 139-147.

29) J. H. Rogerson and J. C. Borland: Effect of the Shapes of Intergranular Liquid on the Hot Cracking of Welds and Castings, Trans. AIME, 227(1963), 2-7.

30) T. Koseki and M. C. Flemings: Solidification of Undercooled Fe-CrNi Alloys: Part I. Thermal Behavior, Metall. Mater. Trans. A. 26A(1995). 2991-2999.

31) N. A. Gjostein, H. A. Domian, H. I. Aaronson and E. Eichen: Relative Interfacial Energies in Fe-C Alloys, Acta Metall., 14(1966), 1637-1644.

32) L. H. Van Vlack: Intergranular Energy of Iron and Some Iron Alloys, Trans. AIME, 191(1951), 251-259.

33) L. E. Murr: Interfacial Phenomena in Metals and Alloys, AddisonWesley Publishing Company, Massachusetts, (1975), 131

34) L. A. Girifalco and R. J. Good: A Theory for the Estimation of Surface and Interfacial Engergies. I. Derivation and Application to Interfacial Tension, J. Phys. Chem., 61(1957), 904-909.

35) K. Nakajima: Estimation of Interfacial Tensions between Phases in the Molten Iron-Slag-Inclusion (Alumina) System, Tetsu-to-Hagané, 80(1994), 383-388. (in Japanese)

36) Handbook on Physical Properties of Molten Iron and Slags, ISIJ,
Tokyo, (1972), 124. (in Japanese)

37) T. Iida and R. I. L. Guthrie: The Physical Properties of Liquid Metals, Clarendon Press, Oxford, (1988), 136-138.

38) T. Ohashi and W. A. Fischer: Formation of Micro Solidification Structures of Steels, Tetsu-to-Hagané, 61(1975), 3077-3091. (in Japanese)

39) H. Mizukami, K. Hayashi, M. Numata and A. Yamanaka: Prediction of Solid-Liquid Interfacial Energy of Steel during Solidification and Control of Dendrite Arm Spacing, Tetsu-to-Hagané, 97(2011), $457-$ 466. (in Japanese)

40) T. Uehara: Phase Field Simulation of Cellular Pattern Formation and Stress Distribution during Directional Solidification, Trans. JSCES, No.20090023(2009). (in Japanese)

41) I. Steinbach and M. Apel: Multi Phase Field Model for Solid State Transformation with Elastic Strain, Physica D, 217(2006), 153-160.

42) S. Nomoto, M. Oba, K. Mori and A. Yamanaka: MicrostructureBased Multiscale Analysis of Hot Rolling of Duplex Stainless Steel Using Various Simulation Software, Integr. Mater. Manuf. Innov., The Minerals, Metals \& Materials Society, 6(2017), 69-82.

43) N. D’Souza, M. G. Ardakani, A. Wagner, B. A. Shollock and M. McLean: Morphological Aspects of Competitive Grain Growth during Directional Solidification of a Nickel-Base Superalloy, CMSX4, J. Mater. Sci., 37(2002), 481-487.

44) A. Wagner, B. A. Shollock and M. McLean: Grain Structure Development in Directional Solidification of Nickel-Base Superalloys, Mater. Sci. Eng. A, 374(2004), 270-279.

45) Y. Z. Zhou, A. Volek and N. R. Green: Mechanism of Competitive Grain Growth in Directional Solidification of a Nickel-Base Superalloy, Acta Mater., 56(2008), 2631-2637.

46) M. Rappaz, J.-M. Drezet and M. Gremaud: A New Hot-Tearing Criterion, Metall. Mater. Trans. A. 30(1999), 449-455.

47) B. Böttger, M. Apel, B. Santillana and D. G. Eskin: Relationship between Solidification Microstructure and Hot Cracking Susceptibility for Continuous Casting of Low-Carbon and HighStrength Low-Alloyed Steels: A Phase-Field Study, Metall. Mater. Trans. A., 44(2013), 3765-3777. 